\title{
Successful management of subdural intracranial empyema linked with cerebral abscess as a consequence of pansinusitis
}

\section{Pansinüzit sonucu oluşmuş serebral apseyle ilişkili subdural intrakraniyal ampiyemin başarılı tedavisi}

Fahrudin ALIĆ ${ }^{1}$, Aldin JUSIĆ ${ }^{1}$, Hakija BEČULIĆ ${ }^{1}$, Nedim BARUČIJA², Enisa IBRAHIMAGIĆ-SULJIĆ ${ }^{3}$

ABSTRACT

This paper reports an unusual case of successful neurosurgical and medical management of subdural empyema combined with cerebral abscess verified by clinical and neuroradiological criteria. It proves that if there is improvement in clinical-neurological condition patient can be discharged after intensive and continuous parenteral antibiotic therapy (1.5-2 months) followed with peroral antibiotic therapy (approx. 1 months) even if the CT abnormalities still persist i.e. CT improvement may lag behind clinical improvement.

Keywords: Intracranial suppurative collection, contiguous and hematogenous spread, surgical vs. pure medical management öz

Bu makale, klinik ve nöroradyolojik kriterlerle doğrulandığı gibi serebral apseyle kombine subdural ampiyemin başarılı bir şekilde tedavi edildiği olağandışı bir olguyu bildirmektedir. BT anormal bulguları hâlâ sebat etse (BT de iyileşme klinik iyileşmeden sonra oluşabilir.) bile yoğun ve devamlı parenteral antibiyotik tedavisi (1,5-2 ay) sonrası oral antibiyotik tedavisiyle (yaklaşık 1,5-2 ay) iyileşme olduğu takdirde hastanın taburcu edilebildiğini kanıtlamaktadır.

Anahtar kelimeler: Intrakraniyal süpüratif koleksiyon, komşuluk veya kan yoluyla yayılım, cerrahi veya yalnızca tıbbi tedavi

\section{INTRODUCTION}

Pansinusitis is the most common source of suppurative intracranial and intraorbital infections ${ }^{1}$. Among the most common intracranial complications we distinguish subdural empyema, epidural abscess, intracerebral abscess, meningitis, cavernous sinus thrombosis, and thrombosis of other dural sinuses ${ }^{2}$. Subdural empyema is a suppurative infection which has no anatomic barrier to spread all over the brain convexity and into interhemispheric fissure unlike brain abscess which is surrounded by tissue reaction, fibrin and collagen capsule formation ${ }^{3}$. Brain abscess and subdural empyema are serious infections which can be stem from chronic suppurative diseases, congenital cardiomyopathy, consequences of head injury or neurosurgical intervention, but the most frequently from chronic sinusitis or otitis ${ }^{4}$. It favours male population with a male/female ratio of 3:1 and it is mostly associated with sinusitis ${ }^{5}$. There are three pathways for pathogens to spread and enter into brain tissue, namely contiguous, and hematogenous spread, and through unknown mechanisms ${ }^{6}$. Intracranial suppurative but loculated collection is mainly caused by streptococcus species ${ }^{6}$. Complaints related to increased intracranial pressure, meningeal irritation, and signs of cerebritis are the most frequent symptoms ${ }^{7}$. Prognosis and final outcome have changed owing to introduction of antibiotherapy, improvement in microbiological identification techniques, and most importantly technological development. Magnetic resonance imaging (MRI) is a gold stan-

Received: 12.09 .2017

Accepted: 28.10 .2017

Department of Neurosurgery, Cantonal Hospital Zenica, Bosnia and Herzegovina ${ }^{1}$, Department of maxillofacial surgery, Cantonal Hospital Zenica, Bosnia and Herzegovina ${ }^{2}$, Department of infectious diseases, Cantonal Hospital Zenica, Bosnia and Herzegovina ${ }^{3}$

Yazışma adresi: Fahrudin Alić, Department of Neurosurgery, Cantonal Hospital Zenica, Bosnia and Herzegovina

e-mail: alifahrudyn@gmail.com 
dard $^{8}$, but its combined use with diffusion-weighted image (DWI) sufficiently differentiates brain abscess from other intracranial loculated lesions ${ }^{9}$. Only in a quarter of patients pathogen can be identified from blood cultures and cerebrospinal fluid ${ }^{9}$. Management of intracranial suppurative complication consists of antimicrobial therapy and complete surgical evacuation and lavage of purulent material ${ }^{10}$.

We represent a case of subdural empyema in which adequate surgical and medical treatment led to a surprisingly positive outcome, even though CT abnormalities still persisted i.e. CT improvement may lag behind clinical improvement.

\section{CASE REPORT}

A 40-year-old Caucasian was admitted to the neurological department in mid-March 2017 due to signs of increased intracranial pressure (ICP), left hemiparesis and movement disorders. Drug treatment did not subside unbearable headache, photophobia and lethargy. At the time of admission the patient was afebrile with no signs of recent head trauma, surgical intervention or systemic infection. Baseline laboratory findings had referent values with slight leukocytosis.

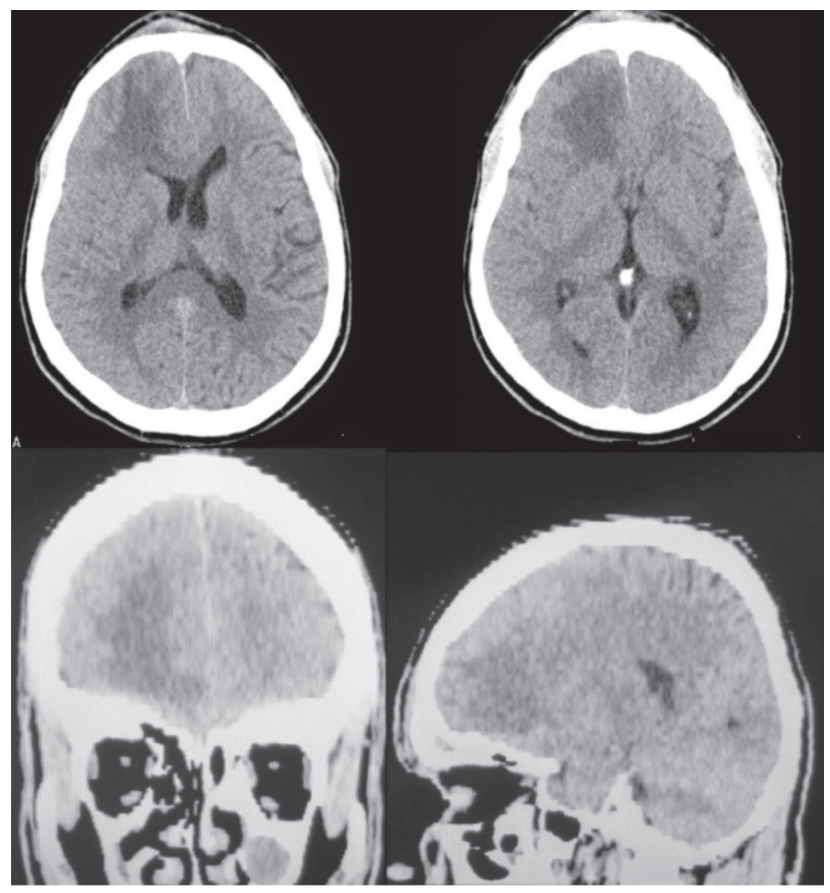

Figure 1. Axial, sagittal and coronal scan of computed tomography (CT) which shows frontal right zone of reduced density.
Routine computed tomography (CT) exam showed frontal right zone of reduced density about $48 \times 32.5$ $\mathrm{mm}$ (Figure 1). On magnetic resonance imaging (MRI) T2, 50x40x57 mm sized oval expansionary mass was observed in the right frontal lobe with irregular perifocal edema without midline shift (Figure 2). During the diagnostic evaluation the physicia should be alert for the presence of sopor, hyperpyrexia, leucocytosis $\left(45.15 \times 10^{9} / \mathrm{L}\right)$, CRP $284.00 \mathrm{mg} / \mathrm{L}$, left hemiplegia and right mydriasis with MRI-verified massive subdural empyema of the right hemisphere, right frontal cerebral abscess, signs of subfalcine herniation and midline shift $>15 \mathrm{~mm}$ (Figure 3). The patient was scheduled for emergency surgery which included decompression, lavage of puddle collection and evacuation of cerebral abscess (Figure 4). Content of pus, cerebrospinal fluid (CSF), two blood (BC) and urine samples (UC) were sent for antibiogram. Without antibiogram wide spectrum antibiotics (Cephtriaxon 2x2 gr, Metronidazole $3 \times 500 \mathrm{mg}$, Orbenin $4 \times 3 \mathrm{gr}$ ), antiedematous and antiepileptic therapy were administered. Due

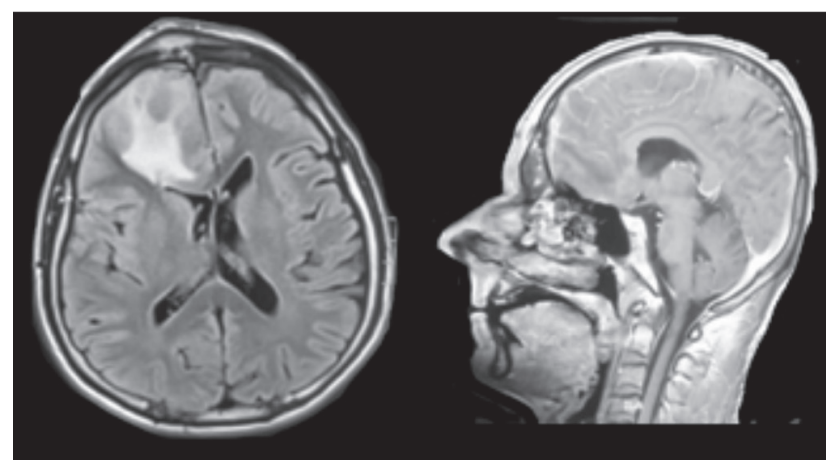

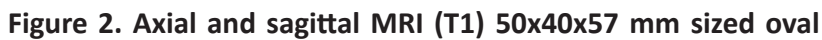
expansionary mass in the right frontal lobe with irregular perifocal edema without midline shift.

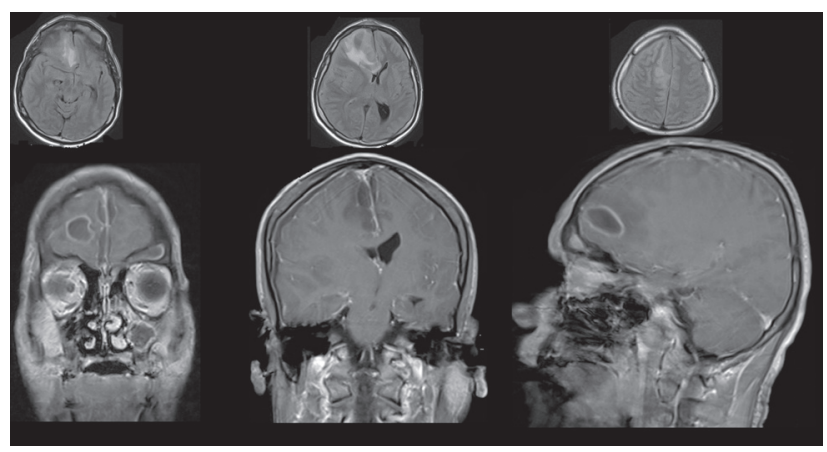

Figure 3. Magnetic resonance imaging (MRI) T1 verified massive subdural empyema of the right hemisphere, right frontal cerebral abscess, signs of subfalcine herniation and midline shift >15 mm. 


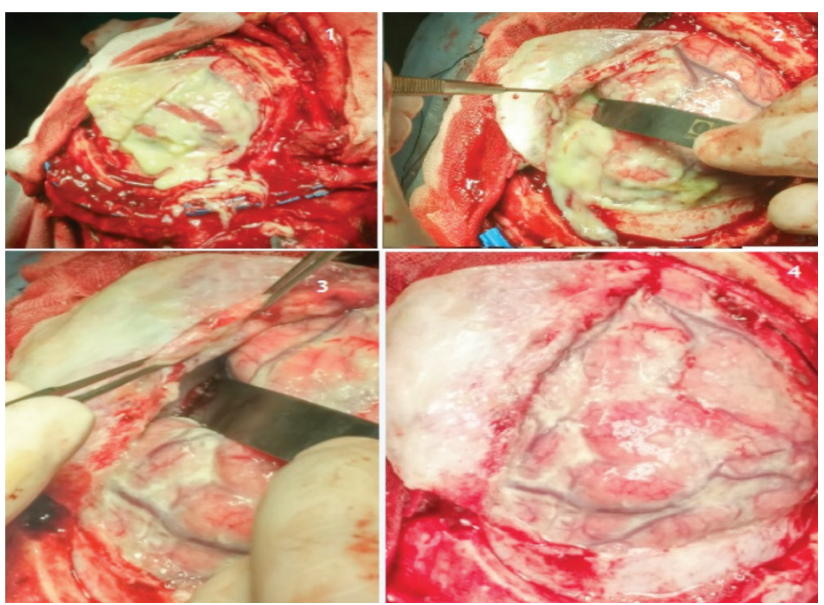

Figure 4. Intraoperative aspect of decompression and lavage of puddle collection.

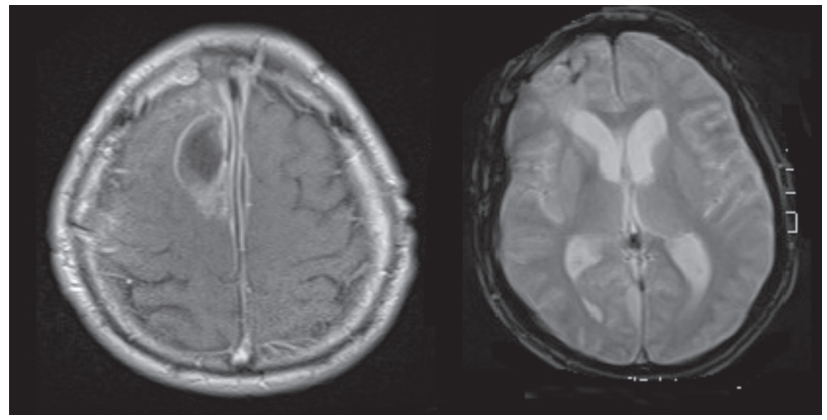

Figure 5. Axial MRI T1 (left) and T2 (right) showed signs of residual interhemispheric and convexity subdural pus collections.

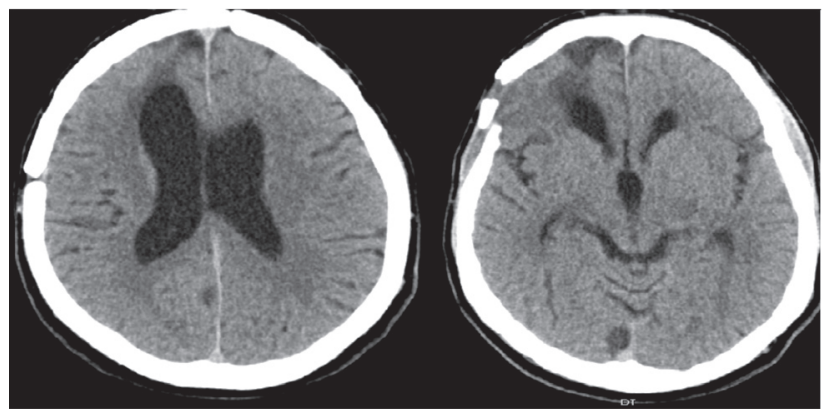

Figure 6. Axial scan of computed tomography (CT) which shows complete regression of purulent content six months later.

to clearly verified pansinusitis trepanatio, lavage of frontal sinus was performed with medicated washout solution. Since control CT scans showed retetion of pus collection, antibiotic therapy was modified (Imipenem $3 \times 1 \mathrm{gr}$ ). Antibiotic susceptibility test results for blood, urine, CSF and puddle content were negative. CSF analysis showed liquor under slightly elevated pressure, hyperproteinemia, and increased number of cells. One month after continuous parenteral antibiotic therapy the patient condition was getting gradually better with regression of left hemiplegia up to normal motor strength and full state of consciousness. He was involved in active physical treatment, verticalized and mobilized. Given the surprisingly good clinical improvement, the patient was discharged with recommended per oral antibiotic therapy even MRI showed signs of residual interhemispheric and convexity subdural pus collections (Figure 5). After a six-month follow-up period, the patient was neurologically intact with complete regression of the purulent collections confirmed by CT scan (Figure 6). Finally, the patient received a prophylactic antibiotic (Extencilline) and antiviral (Pneumo 23) therapy recommended by the infectious diseases specialist.

\section{DISCUSSION}

Half of pansinusitis complications are intracranial and include intracranial abscess, subdural empyema, epidural abscess, cavernous sinus thrombosis, and thrombosis of other dural sinus ${ }^{1}$. Nevertheless, the most common sinusitis-associated complication is subdural empyema ${ }^{2}$ which was confirmed by our case. It is less common than cerebral abscess with a ratio of $5: 1^{3}$. In accordance with literature data the disease favours male population with a male/female ratio of 3:1.

Via three pathways pathogen spreads and enters into the brain tissue: contiguous- in half of the cases, hematogenous- in one third of the cases and unknown mechanisms in the remaining cases $^{6}$. Clinical presentation of intracranial infections is marked with symptoms of increased intracranial pressure, meningeal irritation, and signs of cerebritis ${ }^{7}$. Hallmark of subdural empyema is a nonspecific clinical picture with gradual onset and rapidly developing signs of deterioration which require prompt surgical intervention. Almost identical scenario of events was described in our case.

Radiological imaging, as part of diagnostic evaluation, should be done in patients with suspect subdural empyema. Initial stages of the subdural empyema do not have to show in the classical radiological image, and therefore special attention should be paid to control CT images when SDE presents as a thin, hypodense subdural lesion, with linear enhancement of 
the medial surface ${ }^{7}$. If time allows perform magnetic resonance imaging (MRI) which shows hypointense areas of purulence on T1-weighted images which are hyperintense on T2-weighted images ${ }^{8}$. Nevertheless, MRI as a "gold standard" combined with diffusionweighted (DWI) is sufficient in the differentiation of brain abscess from other intracranial lesions ${ }^{9}$.

Management of intracranial suppurative complication consists of antimicrobial therapy and surgical management. Drug treatment consists of ceftriaxone or cefotaxime combined with metronidazole ${ }^{9}$, but meropenem may be considered as alternative in patients with contraindications or in patients whose broad spectrum antimicrobial therapy did not give desired results as was the case with our patient. A retrospective Spanish study showed similar outcomes for patients treated with cefotaxime plus metronidazole and for those treated with meropenem ${ }^{12}$. Often, duration of parenteral antibiotic therapy is 6-8 weeks (most commonly 6 zweeks) followed by oral antibiotherapy for 4-8 weeks which should be guided by clinical and radiographic response. The "spider web" in which we can often fill up is created after the surgical treatment and the initial period of antibiotic therapy. Namely, control radiographic images can show the same or even worse condition that can lead us to a dead end i.e. unnecessary reoperation. Our experience tells us that it is necessary to adhere to antibiotic treatments for an exact amount of time as suggested by current guides. After that, if clinical status allows, patient may then be discharged even if the CT abnormalities persist i.e. CT improvement may lag behind clinical improvement ${ }^{3}$.

Surgical treatment of subdural empyema is irrelevant and include decompression hemicraniectomy, complete evacuation and lavage of purulence ${ }^{11}$. On the other side, treatment of brain abscess includes aspiration of the pus or excision of the abscess. Small abscesses $\leq 2 \mathrm{~cm}$ in the cerebritis stage respond well to medical therapy alone. However with this approach the source of infection is not resolved so definitive management of the infected sinuses should be done which includes sinus trephination, irrigation and washout. As endoscopic surgery develops this form of otorhinolaryngological treatment is beco- ming more and more popular ${ }^{13}$.

\section{CONCLUSION}

The case shows incessantly unrecognizable cerebritis with the consecutive development of subdural empyema, intracerebral loculated purulent collection and signs of subfalcine herniation. From the present case, it is clear that this neurosurgical emergency requires as quick as possible diagnosis and a combined surgical, and medical treatment. It proves that these neurosurgical entities can be treated successfully only if we strictly adhere to therapeutic guidelines.

\section{REFERENCES}

1. Osborn, Melissa K., and James P. Steinberg. "Subdural empyema and other suppurative complications of paranasal sinusitis." The Lancet infectious diseases 7.1 (2007): 62-67. https://doi.org/10.1016/S1473-3099(06)70688-0

2. Jones NS, Walker JL, Bassi S, Jones T, Punt J. The intracranial complications of rhinosinusitis: can they be prevented? Laryngoscope. 2002;112:59-63.

https://doi.org/10.1097/00005537-200201000-00011

3. Greenberg, Mark S., and Nicolas Arredondo. "Handbook of neurosurgery." (2016).

4. Carpenter J, Stapleton S, Holliman R. Retrospective analysis de 49 cases of brain abscess and review of the literature.Eur J CinMicrobiol Infect Dis, 2007;26:1-11.

https://doi.org/10.1007/s10096-006-0236-6

5. Dill SR, Cobbs CG, McDonald CK. Subdural empyema: analysis of 32 cases and review. Clin Infect Dis. 1995;20:372-86. https://doi.org/10.1093/clinids/20.2.372

6. Brouwer MC, Coutinho JM, van de Beek D. Clinical characteristics and outcome of brain abscess: systematic review and meta-analysis. Neurology. 2014;82:806-13. https://doi.org/10.1212/WNL.0000000000000172

7. Tsai YD, Chang WN, Shen CC, et al. Intracranial suppuration: a clinical comparison of subdural empyemas and epidural abscesses. Surg Neurol. 2003;59:191-96. https://doi.org/10.1016/S0090-3019(02)01054-6

8. Younis RT, Anand VK, Davidson B. The role of computed tomography and magnetic resonance imaging in patients with sinusitis with complications. Laryngoscope. 2002;112:224-9. https://doi.org/10.1097/00005537-200202000-00005

9. Brouwer, Matthijs C, et al. "Brain abscess." New England Journal of Medicine. 371.5 (2014):447-56. https://doi.org/10.1056/NEJMra1301635

10. Bok AP, Peter JC. Subdural empyema: burr holes or craniotomy? A retrospective computerized tomography-era analysis of treatment in 90 cases. J Neurosurg. 1993;78:574-8. https://doi.org/10.3171/jns.1993.78.4.0574

11. Nathoo N, Nadvi SS, Gouws E, van Dellen JR. Craniotomy improves outcomes for cranial subdural empyemas: computed tomographyera experience with 699 patients. Neurosurgery. 2001;49:872-7.

12. Martin-Canal G, Saavedra A, Asensi JM, et al. Meropenemmonotherapy is as effective as and safer than imipenem to treat brain abscesses. Int J Antimicrob Agents. 2010;35:301-4. https://doi.org/10.1016/j.ijantimicag.2009.11.012

13. Gallagher RM, Gross CW, Phillips CD. Suppurative intracranial complications of sinusitis.Laryngoscope. 1998;108:1635-42. https://doi.org/10.1097/00005537-199811000-00009 